\title{
Economic Analysis of Rajma Production in Visakhapatnam District of Andhra Pradesh, India
}

\author{
P. Sruthi ${ }^{1 *}$, B. Aparna ${ }^{1}$, N. Vani ${ }^{1}$ and G. Mohan Naidu ${ }^{2}$ \\ ${ }^{1}$ Department of Agricultural Economics, ${ }^{2}$ Department of Statistics and Computer \\ Applications, S.V Agricultural College, Tirupati, A.P, India \\ *Corresponding author
}

\section{A B S T R A C T}

\begin{tabular}{|l|}
\hline Key w or d s \\
Rajma, Cost \\
concepts, Net \\
return, Rate of \\
returns
\end{tabular}

In the present study, an attempt has been made to study economic analysis of rajma in Visakhapatnam district with view to study the costs and returns, constraints in production and marketing of rajam. For this purpose, two mandals (Chintapalli and Gudem Kotha Veedhi) were selected and from each mandal two villages on the basis of highest area under rajma. From each selected village 10 farmers were selected through simple random technique making a sample size of 40 farmers. The data pertains for the year 2018-19. The study revealed that by using the mentioned physical inputs the main produce was 8.4 quintals per hectare. The total cost of cultivation of rajma per hectare was calculated as ₹ 18869.11. Among the total costs, 86.61 per cent was occupied by variable costs and remaining 13.38 per cent was occupied by fixed costs. The cost of cultivation of rajma according to cost concepts was calculated and they were, cost $A_{1} ₹ 14042.35$, cost $B_{1}$ ₹ 14167.11 , cost $B_{2} ₹ 15677.11$, cost $C_{1} ₹ 17269.11$, cost $C_{2} ₹ 18869.11$ and finally cost $C_{3}$ $₹ 20756.02$. Gross returns and net returns per hectare of rajma were ₹ 52500 and ₹ 33630.89 respectively. When Rate of returns was worked out they stood at 1.78 . High infestation of disease and pest in the field was the major constraint faced by farmers' during cultivation of rajma.

\section{Introduction}

India is a major pulses growing country in the world. The diverse agro-ecological conditions in the country are favorable for growing various pulses. Rajma is scientifically known as Phaseolus vulgaris which is cultivated as vegetable and seed crop. It is also known as red kidney beans, French bean, haricot bean, snap bean, dry bean, pole bean, etc. It is native of South and Central America which is widely cultivated in tropical, sub tropical and temperate regions. The major exporting countries of rajma are USA, China and Argentina. Brazil is top producer of kidney beans in the world (Anonymous, 2013). Rajma is traditionally a crop of temperate region. It is grown in different states of India like Maharashtra, Jammu and Kashmir, Himachal Pradesh, Uttarakhand, West Bengal, Uttar Pradesh, Karnataka, Tamil 
Nadu and few regions of Andhra Pradesh. The total cultivated area under rajma in Andhra Pradesh was 12000 ha (2018-19) (Anonymous, 2018).

Kidney beans have become famous all over the world due to its health benefits as well as their savory texture and are termed as "King of Nutrition". The beans of 100 grams consists energy $1,393 \mathrm{~kJ}$ (333 kcal), carbohydrates $60.01 \mathrm{~g}$, sugars $2.23 \mathrm{~g}$, dietary fibre $24.9 \mathrm{~g}$ and Fat $0.83 \mathrm{~g}$ (Parmar, 2016). There are many health benefits of rajma such as it helps in preventing cancer, improve brain function, control blood sugar levels and may prevent diabetes.

The main objectives of this study to estimate the costs and returns of rajma cultivation. And also to recognize constraints faced by the farmers in production and marketing of rajma.

\section{Materials and Methods}

The study was carried out in Visakhapatnam district of Andhra Pradesh which has been selected purposively for the study because the district has large cultivation area under rajma. Two mandals were selected which has maximum average under rajma and from each mandal two villages were selected based on highest area under the crop. From each selected village 10 farmers were selected through simple random technique making a sample size of 40 farmers.

\section{Tools of analysis}

\section{Cost concepts}

Cost concepts defined by Commission for Agricultural Costs and Prices (CACP) were followed to estimate the cost of cultivation and derive the measures of efficiency viz., farm business income, family labour income, net income and farm investment income cost concepts were used. The cost concepts viz., $\operatorname{cost} A_{1}, \operatorname{cost} A_{2}, \operatorname{cost} B_{1}$, cost $B_{2}$ and cost $C_{1}$, $\operatorname{cost} C_{2}$, cost $C_{3}$ were used in the present study and they are derived as follows.

\section{Cost A1}

This cost includes values of hired human labour, owned and hired cattle labour, owned and hired tractor services, seeds, fertilizers, farm yard manures, plant protection chemicals, depreciation, repairs, land revenue and interest on working capital.

$\operatorname{Cost} \mathbf{A}_{2}=$ Cost $A_{1}+$ Rent paid for leased in land

Cost $\mathbf{B}_{1}=$ Cost $A_{2}+$ Interest on value of owned fixed capital assets (excluding land) $\operatorname{Cost} \mathbf{B}_{2}=$ Cost $\mathrm{B}_{1}+$ Rental value of owned land and rent paid for leased-in land

Cost $\mathbf{C}_{1}=$ Cost $\mathrm{B}_{1}+$ Imputed value of family labour

$\operatorname{Cost} \mathbf{C}_{2}=$ Cost $\mathrm{B}_{2}+$ Imputed value of family labour

Cost $\mathbf{C}_{\mathbf{3}}=$ Cost $\mathrm{C}_{2}+10$ per cent of cost $\mathrm{C}_{2}$ as management cost. (On account of managerial functions performed by farmers).

\section{Farm efficiency measures}

Farm business income $=$ Gross income - Cost $\mathrm{A}_{1}$ Family labour income $=$ Gross income Cost $\mathrm{B}_{2}$ Net income $=$ Gross income - Cost $\mathrm{C}_{2}$

Farm investment income $=($ Gross income Cost $\left.\mathrm{C}_{3}\right)+\left(\right.$ Cost $\mathrm{B}_{2}-$ Cost A1) Returns per rupee of expenditure $=$ Net income $/ \operatorname{Cost} C_{3}$.

\section{Garrett's ranking technique}

Garrett's ranking technique was employed to prioritize or rank the problems posed by the farmers in production and marketing of rajma. Garratt's Formulae for converting rank into percent is given by: Percent position $=100 *(\mathrm{Rij}-0.5) / \mathrm{Nj}$ 
Where,

Rij=Rank given for $i^{\text {th }}$ factor (constraint) by $j^{\text {th }}$ individual, $\mathrm{Nj}=\mathrm{Number}$ of factor (constrains) ranked by $\mathrm{j}^{\text {th }}$ individual.

\section{Results and Discussion}

\section{Costs and returns of rajma}

Any enterprise to gain profitability depends on its cost structure, output and price received by entrepreneur. Cost structure depends on expenditure made on inputs and services utilized in the process of production.

\section{Cost structure of rajma}

Economic costs include both explicit and implicit costs. To arrive at the profitability of any project these costs should be covered by gross income. Usually farmers feel satisfied only when gross income exceeds explicit costs. More specifically, the total costs were divided in to operational and fixed costs. Hence, the above costs were worked out for per hectare of rajma crop and mentioned in Table 1.

The cost of cultivation of rajma per hectare worked out to ₹ 18869.11 in which the variable cost constituted ₹ 16343.74. Among variable costs it was observed that human labour, seed cost and fertilizer cost constituted the major portion. The high share of labour cost of the total variable cost were also reported by Sanjeev et al., (2017). As high as ₹ 6641 (35.20 per cent) were spent on human labour, ₹ 4000 (21.20 per cent) were spent on seed material and ₹ 1900 (10.07 per cent) were spent on fertilizer. The next highest item of expenditure was cattle labour and machine labour on which rajma farmers spent an amount of ₹ 1895 (10.04 per cent) and 1680 (8.90 per cent). The cost of Interest on working capital cost was ₹ 227.74 (1.20 per cent). The total fixed cost per hectare worked out to ₹ 2525.37 (13.38 per cent). The rented value of owned land was estimated at ₹ 1600 (8.48 per cent). Other fixed costs were depreciation, interest on fixed capital and land revenue were estimated at ₹ 700.61 (3.71 per cent), ₹ 124.76 (0.66 per cent) and ₹ 100 (0.53 per cent).

\section{Cost concepts of rajma}

An attempt was also made to analyze the cost of cultivation of rajma according to various cost concept used by Commission for Agricultural Costs and Prices(CACP), New Delhi and presented in Table 2.

The various costs calculated provide different measures to the cultivator. The difference between gross returns from scale of produce and cost $A$ represents the total returns to the cultivator for fixed and variable inputs employed. Cost $\mathrm{A}_{2}$ provides a measure of return for farmers investment and profit. Cost B provides an estimate of returns which correspond to the own labour and profit. The Cost $\mathrm{C}$ provides an estimate purely of profit of farm.

The Cost $A_{1}$ and Cost $A_{2}$ was found to be the same i.e. ₹ 14042.35 per hectare, it means that none of the respondents were found to be using leased-in land for cultivating rajma. The Cost $\mathrm{B}_{1}$, Cost $\mathrm{B}_{2}$, Cost $\mathrm{C}_{1}$ Cost $\mathrm{C}_{2}$ and Cost $\mathrm{C}_{3}$ was ₹ $14167.11, \quad 15677.11, \quad 17269.11$, 18869.11 and 20756.02 respectively.

\section{Measures of farm income}

Various farm efficiency measures viz., gross income, net income, farm business income, family labour income and farm investment income were computed and presented in Table 2.

Gross income obtained from rajma was ₹ 52500per hectare. Net income which represents surplus of gross income over total 
cost estimated was estimated ₹ 33630.89on rajma farms. Farm business income indicates returns on owned resources like land, labour and capital was ₹ 38457.65.

Family labour income is another measure of farm efficiency representing the returns from farmer's own labour and family labour accounting to ₹ 36732.89. Farm investment income is a measure of returns to fixed capital was ₹ 33468.74 .

\section{Output and returns per hectare of rajma}

The output from any crop depends on the various factors such as climate, fertility of soil, irrigation and quality input material etc. From the Table 3, it is clear that rajma recorded a yield of 8.4 quintal per hectare. The gross returns and net returns obtained from rajma farms were ₹ 52500 and ₹ 33630.89 per hectare respectively. The cost of production of rajma was ₹ 2246.32 and rate of return per rupee spent worked out to 1.78 .

Table.1 Cost of cultivation of rajma according to component wise

\begin{tabular}{|c|c|c|c|c|c|}
\hline S.No. & Particulars & unit & Quantity & value & Percent \\
\hline I. & \multicolumn{5}{|l|}{ VARIABLE COST } \\
\hline \multirow[t]{3}{*}{1} & Human labour & mandays & 17.89 & 6641.00 & 35.20 \\
\hline & Owned & & 8.06 & 3102.00 & 16.44 \\
\hline & Hired & & 9.83 & 3539.00 & 18.76 \\
\hline \multirow[t]{3}{*}{2} & Cattle labour & Pair days & 3.35 & 1895.00 & 10.04 \\
\hline & Owned & & 2.15 & 1175.00 & 6.22 \\
\hline & Hired & & 1.20 & 720.00 & 3.81 \\
\hline \multirow[t]{3}{*}{3} & Machine labour & hours & 2.40 & 1680.00 & 8.90 \\
\hline & Owned & & - & - & - \\
\hline & Hired & & 2.40 & 1680.00 & 8.90 \\
\hline 4 & Seed/ seedlings & $\mathrm{kg}$ & 50.00 & 4000.00 & 21.20 \\
\hline 5 & Manures and Fertilizers & $\mathrm{kg}$ & 100.00 & 1900.00 & 10.07 \\
\hline \multirow[t]{2}{*}{6} & Interest on working capital & & & 227.74 & 1.20 \\
\hline & Total variable costs & & & 16343.74 & 86.61 \\
\hline II. & \multicolumn{5}{|l|}{ FIXED COST } \\
\hline 1 & Land revenue & & & 100.00 & 0.53 \\
\hline 2 & $\begin{array}{l}\text { Rental value of owned land/rent } \\
\text { paid for leased in land }\end{array}$ & & & 1600.00 & 8.48 \\
\hline 3 & Depreciation & & & 700.61 & 3.71 \\
\hline \multirow[t]{3}{*}{4} & Interest on fixed capital & & & 124.76 & 0.66 \\
\hline & Total fixed costs & & & 2525.37 & 13.38 \\
\hline & TOTAL COST & & & 18869.11 & 100.00 \\
\hline
\end{tabular}


Table. 2 Costs concepts and measures of farm income

\begin{tabular}{|l|l|l|}
\hline S. No. & Particulars & Farms \\
\hline $\mathbf{1 .}$ & Cost $\mathrm{A}_{1} / \mathrm{A}_{2}$ & 14042.35 \\
\hline $\mathbf{2 .}$ & Cost $\mathrm{B}_{1}$ & 14167.11 \\
\hline $\mathbf{3 .}$ & Cost $\mathrm{B}_{2}$ & 15677.11 \\
\hline $\mathbf{4 .}$ & Cost $\mathrm{C}_{1}$ & 17269.11 \\
\hline $\mathbf{5 .}$ & Cost $\mathrm{C}_{2}$ & 18869.11 \\
\hline $\mathbf{6 .}$ & Cost $\mathrm{C}_{3}$ & 20756.02 \\
\hline $\mathbf{7 .}$ & Gross Income & 52500 \\
\hline $\mathbf{8 .}$ & Net Income & 33630.89 \\
\hline $\mathbf{9 .}$ & Farm business Income & 38457.65 \\
\hline $\mathbf{1 0}$. & Family labour Income & 36732.89 \\
\hline $\mathbf{1 1}$ & Farm investment Income & 33468.74 \\
\hline
\end{tabular}

Table.3 Output and returns per hectare of rajma

\begin{tabular}{|l|l|l|}
\hline S. No. & Particulars & Rajma farm \\
\hline $\mathbf{1}$ & Yield (Q) & 8.4 \\
\hline $\mathbf{2}$ & Gross Income (Rs) & 52500 \\
\hline $\mathbf{3}$ & Total Cost (Rs) & 18869.11 \\
\hline $\mathbf{4}$ & Net Return (Rs) & 33630.89 \\
\hline $\mathbf{5}$ & Rate of Returns(Net returns/Total Cost) & 1.78 \\
\hline $\mathbf{6}$ & Cost of production & 2246.32 \\
\hline
\end{tabular}

Table.4 Farmers perception on constraints in production and marketing of rajma $(n=40)$

\begin{tabular}{|l|l|l|c|}
\hline S.No. & \multicolumn{1}{|c|}{ Production constraints } & Score & Rank \\
\hline 1. & Unavailability of labour & 77.15 & 1 \\
\hline 2. & High cost of input material & 67.90 & 2 \\
\hline 3. & Non availability of credit on time & 63.65 & 3 \\
\hline $\mathbf{4 .}$ & Disease and pest infestation & 58.50 & 4 \\
\hline $\mathbf{5 .}$ & Inadequate knowledge of package and practices & 53.82 & 5 \\
\hline 6. & $\begin{array}{l}\text { Inadequate knowledge of plant protection } \\
\text { chemicals }\end{array}$ & 53.07 & 6 \\
\hline 7. & Inadequate transportation facility & 48.15 & 7 \\
\hline 8. & $\begin{array}{l}\text { Inadequate awareness about market news and } \\
\text { intelligence }\end{array}$ & 42.15 & 8 \\
\hline 9. & Unfavourable weather conditions & 41.25 & 9 \\
\hline $\mathbf{1 0 .}$ & Inadequate storage facility & 40.05 & 10 \\
\hline $\mathbf{1 1 .}$ & Low price for beans & 33.77 & 11 \\
\hline $\mathbf{1 2 .}$ & Inadequate capital & 27.52 & 12 \\
\hline & & & \\
\hline
\end{tabular}


Constraints faced by the farmers in production and marketing of rajma

The major constraint faced by most of the farmers was unavailability of labour (Mean score 71.15) which stood $1^{\text {st }}$ and the second most important constraint faced by the rajma farmers was high cost of input material (Table 4). The other important constraints reported by the rajma farmers were non availability of credit on time, disease and pest infestation and inadequate knowledge of package and practices which ranked $3^{\text {th }}, 4^{\text {th }}$ and $5^{\text {th }}$ respectively. The constraints such as Inadequate knowledge of plant protection chemicals (Mean score 53.07), inadequate transportation facility (Mean score 48.15) and inadequate awareness about market news and intelligence (Mean score 42.15) are the other problems faced by rajma farmers in production stood $6^{\text {th }}, 7^{\text {th }}$ and $8^{\text {th }}$. The other constraints were unfavorable weather conditions (Mean score 41.25), inadequate storage facility stood (Mean score 40.05), low price for beans (Mean score 33.77) and inadequate capital (Mean score 27.52).The similar constraints were also identified by Shashikant(2011).

In conclusion, the cost of cultivation of rajma per hectare worked out to ₹ 18869.11in which the variable cost constituted ₹ 16343.74and fixed cost worked out to ₹ 2525.37. Rajma has recorded a yield of 8.4 per hectare. The gross returns and net returns obtained from rajma farms per hectare were ₹ 52500 and $₹ 33630.89$ respectively and the rate of return per rupee spent was worked to 1.78 .

According to the cost concept analysis, on an average, Cost $\mathrm{A}_{1} / \mathrm{A}_{2}$, Cost $\mathrm{B}_{1}$, Cost $\mathrm{B}_{2}$, Cost $\mathrm{C}_{1}$ Cost $C_{2}$ and Cost $C_{3}$ were ₹ 14167.11, 15677.11, 17269.11, 18869.11 and 20756.02 respectively. The net income from rajma were ₹ 33630.89. The farm business income, family labour income and farm investment income on rajma farm were ₹ 38457.65 , $₹ 36732.89$ and $₹ 33468.74$ respectively. It was observed that, the major problem in production and marketing of rajma were unavailability of labour followed by high cost of input material, non availability of credit on time and disease and pest infestation.

\section{References}

Anonymous., 2013. Food and Agriculture Organization of the United Nations. FAOSTAT database. Website: http://www.fao.org.

Anonymous., 2019. Agricultural statistics at a Glance 2018-19. Directorate of Economics and Statistics. 83-88.

Gondhali, R.S., Ulemale, D.H and Sarap., S.M. 2017.Economics analysis of Gram in Amravati district. International Research Journal of Agricultural Economics and Statistics. 8(1): 31-36.

Kanade, A.U., Deshmukh, K.V and Shelke, R.D. 2017. Analysis of greengram Production in Marathwada region of Maharashtra. Trends in Biosciences. 10(6):1434-1436.

Parmar, K.2016.Farming of Kidney beans. Rashtriyakrishi. 11(2):51-51.

Sanjeev, Singh, S.P., Bhat, A and Kumar,M. 2017. Economics of rajmash cultivation in Eastern Jammu region. Journal of food legumes. 30(1): 54-56.

Shashikant, V.G., Prabhakar and Manjunatha, B.L. 2011. Constraints in Production and marketing of redgram in Gulbarga district of Karnataka. Journal of Community Mobilization and Sustainable Development. 6(2):202-204. 


\section{How to cite this article:}

Sruthi, P., B. Aparna, N. Vani and Mohan Naidu, G. 2021. Economic Analysis of Rajma Production in Visakhapatnam District of Andhra Pradesh, India. Int.J.Curr.Microbiol.App.Sci. 10(06): 646-652. doi: https://doi.org/10.20546/ijcmas.2021.1006.071 